\title{
Juridical Review Of The Death Penalty In Indonesia In Islamic Law Perspective
}

\author{
Kurniawan Bagus Samudro*) \\ *) Master of Law, Faculty of Law Universitas Islam Sultan Agung
}

Abstract.

This study aims to examine in depth the juridical review of capital punishment in Indonesia from the perspective of Islamic law. This research is expected to contribute ideas in the realm of literature in the field of Islamic law as well as input for observers and law enforcers to determine policies related to the death penalty law. To achieve the target, this research was conducted by observing events or facts that were considered relevant to the research, by collecting primary and secondary data through a juridical-normative approach with qualitative analysis methods.

A study on this theme can be concluded that in the perspective of Islamic law, capital punishment (qisas) reflects justice and balance with the actions perpetrated by the perpetrator against the victim or the imposition of this punishment is in line with the principles of Islamic criminal law and the soul applies benefit to the level of social life. Public.Islamic law through Islamic criminal law (figh al-jinayat, at-tasri ul jinai) has guaranteed, protected and safeguarded the benefit of mankind by establishing a number of rules, either in the form of orders or prohibitions.

Keywords: Death penalty; Islamic law; qisas; benefit.

\section{Introduction}

The Indonesian archipelago appears to be a gathering place for almost all religions in the world. Indonesia is a part of many countries in the world whose legal political development has experienced legal growth without neglecting the significant influence of social and religious values. ${ }^{1}$ With the characteristics of a pluralistic society.

In the realm of legal science, criminal law is one type of law that is applied to society to regulate this life in order to create peace and tranquility. ${ }^{2}$

Being punished by the severity of the types of punishment being punished, Islamic criminal law recognizes 4 (four) types of Jarimah, namely:

a. Jarimah Kisas, namely Jarimah who was threatened with kisas punishment. Kisas is the same punishment as a finger. What includes this Jarimah is deliberate murder and deliberate maltreatment which results in the cutting or injury of limbs.

\footnotetext{
${ }^{1}$ Muladi. "Pengembangan Hukum Pidana Dalam kontek Negara Kebangsaan”. in Arifin, Jaenal., \& Salim, M Arskal (ed). (2001). Pidana Islam Di Indonesia Peluang, Prospek, dan Tantangan. Jakarta: Pustaka Firdaus. h 24-25

${ }^{2}$ The element of Punishment as a Retaliation is implied in the word Pidana. See Prododikoro, Wirdjono. (2003). Asas - asas hukum Pidana di Indonesia. Bandung: PT Refika Aditama. h. 1.
} 
b. Jarimah diyat, namely Jarimah who is threatened with diyat punishment. Diyat is a punishment compensation for the suffering experienced by the victim or his family. This Jarimah includes accidental murder and accidental maltreatment which results in the cutting or injury of limbs.

c. Jarimah hudud, namely Jarimah who is threatened with hadd punishment. Hadd is a punishment that has been determined in the verse of the Qur'an or the Sunnah of the Prophet and it is certain of its kind and is the right of Allah, it cannot be replaced by other kinds of punishment or completely canceled by humans. Which includes this finger is theft, robbery, rebellion, adultery, accusing adultery, drinking alcohol and riddah.

d. 4. Jarimah ta'zir, namely Jarimah who is threatened with ta'zir punishment. Jarimah ta'zir has various kinds mentioned in the text, but the types of punishment are left to the ruler to determine and there are both types of Jarimah and the threat of punishment which are fully left to the ruler. ${ }^{3}$

The type of punishment in criminal law, one of the most controversial in its existence in the national criminal law, is the death penalty. This is because of the many conflicts from various circles and observers of the law, because of the argument that the crime is not intended to improve the convict, not by ending the convict's life.

The Criminal Code (KUHP), previously known as Wetboek van Strafrecht (WvS), regulates the types of crimes consisting of: main and additional crimes. One of the types of punishment included in the principal punishment is death penalty; besides imprisonment, imprisonment, fines and cover. This death penalty is the heaviest legal sanction after a life sentence. ${ }^{4}$ Even though there are differences of opinion regarding the purpose of the crime, there is one thing that cannot be denied that the application of punishment in this criminal area is one of the means to prevent crime and improve the convict (rehabilitation). Thus, capital punishment can be said to be an attempt to retaliate against a criminal act committed, as well as to prevent the public from participating in the crime.

A heterogeneous philosophical review of the nation and society of Indonesia which is based on Pancasila, makes it possible for Islamic law to become part and development of Indonesian national law. However, what is still a problem and even tends to be considered controversial is how Islamic law in the criminal field can become part of positive law in the context of developing a national criminal law.

Efforts to reform the Criminal Code which in recent years have been being disseminated in the academic world necessitates a critical and constructive comparative study. This tendency is carried out by the existence of calls for a value-oriented approach, both human values, cultural identity values, and religious moral values. ${ }^{5}$

\footnotetext{
${ }^{3}$ Basyir, Ahmad Azhar. (2001). Ikhtisar Fikih Jinayat (Hukum Pidana Islam). Yogyakarta ,: UII Press. h. 7.

${ }^{4}$ The provisions regarding the types of punishment are contained in article 10 of the Criminal Code on Criminal Code. Meanwhile, additional penalties include: revocation of certain rights, confiscation of certain items, and announcement of a judge's decision. See Adji, Oemar Seno et al (ed). 1986. . Kitab Undang-Undang Hukum Pidana (KUHP). Jakarta: Ghalia Indonesia, p. 30

5 Muladi, loc.Cit.
} 
Until now, Indonesia's national criminal law still has a death penalty mechanism, ${ }^{6}$ and recognized as part of criminal law. The Criminal Code, which was previously known as Wetboek van Strsfrecht (WvS), is a legacy of Dutch colonialism which was passed on January 1, 1918 after the unification of all criminal laws for certain national groups which then applied to all groups of the population of the Dutch East Indies. ${ }^{7}$

The execution of the death penalty is no longer carried out by an executioner on the gallows as written in Article 11 of the Criminal Code, but by being shot to death by a group of firing squad and not carried out in public. ${ }^{8} \mathrm{One}$ of the changes in the execution mechanism is because the death penalty is constantly being opposed and made into an international human rights issue. Therefore, this mechanism of punishment which is more polite, closed and secret is one of them is a vehicle to reduce turmoil.

Islamic law with its criminal law, that to guarantee, protect and safeguard the benefit of mankind, Islam establishes a number of rules, either in the form of orders or prohibitions. This set of rules is called Islamic criminal law (Fiqh aljinayat, at-tasyri'ul jinai). Among the important elements in Islamic criminal law that need to be explained in this case are acts that violate the rules (law) which are commonly called Jarimah or jinayah and the threat of punishment (criminal threat, 'uqubah). ${ }^{9}$ One form of the punishment in Islamic law is the death penalty.

Jinayat law is part of the whole Islamic law. The word 'Jinayah' is specifically for actions that threaten the life of a person or limb, such as killing, injuring, hitting and so on. Meanwhile, the word 'Jarimah' is used for crimes that do not involve the soul and limbs, such as stealing, adultery, robbing and others. As for what is meant by jinayah law is the prohibition of Allah on which offenders are threatened with certain penalties. Why is that action prohibited by Allah, because the act according to its form and nature is detrimental to a person or society, or in other words the act is against the will of Allah for the happiness of the servant.

In Islamic criminal law, there are punishments that are commensurate with criminal acts or what the provisions of the Shari'a say are qisas penalties, namely punishments that are equal and equal to the crimes committed by the perpetrator of the criminal act. In general qisas ${ }^{10}$ and diyat ${ }^{11}$ is a punishment which is

\footnotetext{
${ }^{6}$ The articles on the death penalty in various legal provisions include, among others, several articles in the KUHP, plus provisions outside the Criminal Code, namely Law No.22 of 1997 concerning Narcotics, Law No. 5 of 1997 concerning Psychotropics, Law No. 31 of 1999 concerning Corruption Eradication, Law no. 26 of 2000 concerning Human Rights Courts and the repeal of the death penalty in the Perpu / Bill on the Eradication of Terrorism.

7 Prodjodikoro,Wirjono. op. cit. h. 8

8 This is in accordance with the provisions of Law No.2 / Pnps / 1964 concerning the Procedure for the Implementation of the Death Penalty.

${ }^{9}$ Hosen, Ibrahim. (1997). "Jenis-jenis Hukuman dalam Hukum Pidana Islam (Reinterpretasi terhadap Pelaksanaan aturan)", in Jamal D. Rahman, (1997). Wacana Baru Fiqih Sosial 70 tahun KH. Ali Yafie. Jakarta: Mizan, p. 91.

10 Etymologically, qisas is equality and balance, meaning that the punishment is the same and is balanced with the crime committed by the perpetrator of the criminal act.

11 Meanwhile, diyat is a certain amount of property that must be given to the victim (his family) as punishment.
} 
punishable by various kinds of criminal acts in the form of crimes against soul and body. ${ }^{12}$

A review of the existence of the death penalty is very necessary, in addition to being right on target, it must also refer to other legal principles and heed universal humanitarian principles. It is here that we want to emphasize whether the application of the death penalty is in line with the functions and objectives of law formation and the context of national law in Indonesia. In addition, the philosophical side in the perspective of Islamic law in Indonesia regarding the death penalty is a debate that becomes interesting to elaborate, in order to conduct an in-depth study to what extent the relevance of this crime is applied.

\section{Research methods}

The approach method used in this research is the normative juridical approach method. The specification used in this research is descriptive analytical. The research data consisted of: primary data taken by the method of observation or observation and interview / interview, secondary data and tertiary data which was taken by the method of literature. The data that has been collected is then presented in the form of a thesis report, the analysis technique used in this research is qualitative analysis, namely the data that has been collected and then arranged systematically, then analyzed in order to find clarity on the issues discussed.

\section{Research Results and Discussion}

In the world of Islamic thought, the term democratic shari'ah is known, which is a term used to facilitate understanding of Islamic thought products which are based on critical, contextual and historical studies. These products of thought in general have the ambition to restore the fundamental Islamic spirit, which has been manipulated and reduced by classical Islamic thinkers and codified in the form of sacred fiqh, and accepted by the Islamic community without reservation. The product of thought based on the principle of progressive revelation with a liberal interpretation is the democratic shari'ah. Democratic shari'ah is a shari'ah that is acceptable to the socio-political context of a nation and at a time. ${ }^{13}$

Islam with a mission to embody the protection of human rights (al-huquq al-insaniyyah fi al-Islam) is called the proposal of al-khams (five basic principles). These five basic principles have a very deep connection and relevance, and of course they are in line with the human rights principles that have been echoed by many parties. The five basic principles include:

a. hifzh al-din, namely to guarantee the right of Muslims to maintain their religion and beliefs.

b. Hifzh al-nafs wa al-irdh, namely to guarantee the right of every human soul (life) to grow and develop properly.

\footnotetext{
${ }^{12}$ About qisas and diyat said by Allah SWT in various words, including, QS. Al-Baqarah (2): 178, QS. Al-Maidah (5): 45, QS. An-Nisa (4): 92.

${ }^{13}$ Hasani, Ismail "Islam and Human Rights", source hukumonline, December 23, 2003.
} 
c. Hifzh al-'aql, namely the guarantee of freedom of expression, on the platform, issuing opinions / opinions, conducting research and various other scientific activities.

d. Hifzh al-nasl, namely the guarantee of the privacy of every individual, profession, guarantee of the future, the continuity of their better and better quality offspring.

e. Hifzh al-mal, namely all guarantees of ownership of property, property, and so on. By preserving this property, Islam strictly prohibits actions that seek to take away the rights of others such as stealing, robbing and other actions that violate the law. ${ }^{14}$

Imposing the death penalty on a person accused of committing a criminal act means ending a person's right to life through a judge's verdict for a particular crime. Thus, a person's right to life has been revoked or his freedom to continue his life has been limited by the execution of a sentence against him. Whereas the right to life is a fundamental human right and cannot be revoked by anyone, including for any reason, including the state under the pretext of law enforcement. 15

The opinion that states that capital punishment is contrary to the 1945 Constitution is highly neutralized by the statement that the constitution, apart from guaranteeing human rights, allows human rights to be limited, provided that it is in accordance with applicable legal provisions, or for the sake of considerations of morality, order and security of the wider community. ${ }^{16}$

According to the author, until whenever the death penalty is still needed for perpetrators of serious crimes, such as premeditated murder which is carried out sadistically, including perpetrators of genocide and crimes against humanity, drug traffickers, big corruptors and terrorists. However, it is true that the technical implementation of the execution needs to be revised, so as to reduce the pain of the convicted person, for example by using a painless injection.

Many reviewers stated that Islamic law is a space for the expression of religious experience which is very important in the life of Muslims. They claim that, "Islamic law is an overview of Islamic thought, the most typical manifestation of the Muslim way of life and is the essence of Islam itself". ${ }^{17}$ The law introduced by the Koran is not something that stands alone, but is an integral part of the rules. The rule about Allah who created the universe, regulates it, maintains it, and takes care of it so that all creatures live their respective lives well and carry out their

\footnotetext{
14The description of this maslahah is pretty much determined in various fiqh literature and the proposal of al-fiqh. But in the complete work of Ash-Syatibi See Asy-Syatibi, Abu Ishaq alMuwafaqat ...., 3-4 see also, Imam al-Ghazzali Said, et al (ed). (2005), Ahkam al-Fuqaha Solusi Problematika Aktual Hukum Islam Keputusan Muktamar, Munas dan Kombes Nahdlatul Ulama (1926-1999 AD), Surabaya: LTN NU East Java \& Diantama. h. 621-622.

${ }^{15}$ The right to life is regulated in article 3 of the Universal Declaration of Human Rights, article 28 I paragraph (1) of the 1945 Constitution, article 9 paragraph (1) of Law no. 39 of 1999 concerning Human Rights, article 6 of the International Convention on Civil and Political Rights adopted by the United Nations 16 December 1966.

16 For legitimacy, see article 28 j 1945.

${ }^{17}$ Schacht, Joseph. (1964). An Introduction to Islamic Law, Oxford: Oxford University Press, I.
} 
respective functions in an orderly manner. Allah's law covers all creatures (the universe). ${ }^{18}$

Placing Islamic law as an autonomous institution and an important part of the Islamic element is difficult to understand without relating it to the development of the socio-political situation that develops in the midst of society. This is because the socio-political setting has contributed to the shape and color of the survival of an institution. This also applies and affects other social community institutions.

This assumption is reinforced by Noel J.Coluson's thesis, ${ }^{19}$ that the law always lives and develops in line with the rate of development of a society. This opinion can be easily proven sociologically, where the ideals of law are implemented ${ }^{20}$ and legal awareness is also shaped by the socio-political configuration that develops in the level of social life, including those developed by a government regime. Therefore, in other words, everything related to social phenomena certainly cannot stand alone, but will always be influenced or influenced by the socio-political environment that surrounds it, both the law itself and other religious institutions.

According to Philip K. Hitti, from birth Islam has always been associated with statehood, society, and political and religious unity (ad-din wa daulah). ${ }^{21}$ In the context of political law, it is said that Islamic law and politics are two inseparable sides of an Islamic society. Islamic law without political support will be difficult to extract. Meanwhile, politics that ignore Islamic law will cause chaos in society. So the better the relationship between Islam and politics, the greater the opportunity for Islamic law to be actualized, and vice versa.

It is hoped that the above analysis can serve as a perspective in understanding how the juridical review of capital punishment in Indonesia is from the perspective of Islamic law. The death penalty, or what in some terms of Islamic law is stated as the law of suicide (qisas, a sentence equal to or proportional to the crime committed) is the best punishment as its name implies. Death penalty is carried out because it reflects justice and balance with the actions perpetrated by the perpetrator against the victim. In other words, the existence of this capital punishment can be traced from several decrees of Allah in the Koran which the author emphasizes.

In Islamic law, the manifestation of legal values can (1) be universal; (2) humanitarian; and (3) moral. The value of law is universal, meaning that the law is truly capable of protecting and protecting the objectives of the law itself, the value of law is humanitarian means that the law truly respects the position and status, both individually and in society, and the legal value is moral, which means the law

\footnotetext{
${ }^{18}$ Yafie, Ali, "Konsep-konsep Hukum", in Budhy Munawar-Rahman (ed), 1995, Kontekstualisasi Doktrin Islam dalam Sejarah. Jakarta: Paramadina Foundation, Cet. II, 85.

${ }^{19}$ Coulson, Noel J. (1991). A History of Islamic Law, Edinburgh: University Press, I.

${ }^{20}$ Ideals of law are ideas, create feelings and thoughts. The meaning used here is in line with the opinion of Rudolf Stamier (1956-1939)

${ }^{21}$ Hitti, Philip K. (1973). The Story of Arabs, London: MacMillin, p. 116. see also Azhary, M. Tahir. (1997). Negara Hukum Suatu Studi Tentang Prinsip-prinsip dilihat dari Hukum Islam Implementasinya pada Periode Madinah dan Masa Kini, Jakarta: Bulan Bintang. h. 38. Similar thing, Haikal, M. Husain. (1982). Sejarah Hidup Muhammad, Jakarta: Pustaka Jaya and Tintamas. p. 218.
} 
is truly has the moral strength for all levels of law users to submit and obey the orders and prohibitions because the Prophet Muhammad was sent only to perfect noble character. ${ }^{22}$

According to al-Gazzali, maslahat can be accepted as a way to find law on condition that it is in line with the objectives of the law. The purpose of this law can be identified by conducting a comprehensive study of the verses of the Koran, as-Sunnah, and Ijma 'which, although not stated by a specific proposition, can be understood from all the arguments and contextual instructions. On that basis, if maslahat is understood as defending the aims of law, then there is no reason to reject it, it must even be ascertained as evidence. Even though there are differences of opinion, only in the matter of conflict between problems and when it is obligatory to accept the stronger benefit. ${ }^{23}$

According to the author, the location of the relevance of giving priority to benefit and should also be a priority for Islamic law in the issue of the application of qisas punishment. Thus, as stated in the previous section, that capital punishment is intended to guarantee recognition and respect for the rights and freedoms of others and to fulfill demands for justice in accordance with considerations of moral, religious values, security and public order. Some others argue that the definition of the right to life in the 1945 Constitution is a right in which people cannot be killed arbitrarily, such as genocide. The right to life means that people receive protection from arbitrary actions, which can result in death.

Killing in the view of Islam, or actions that fall under the category of crimes regulated in several articles of the Criminal Code and other laws are very destructive, disturbing public order and life, this needs to be repaid with law enforcement (law inforcement) and the existence of legal justice (justice). of punishment). Large-scale crimes against humanity (extra-ordinary crimes) such as terrorism, treason against the state, psychotropic narcotics crimes, and so on require a punishment mechanism that is appropriate to achieve peace in society. The Qur'an explains that the magnitude of the sin of taking another's life is tantamount to killing the soul of a human being entirely, Allah states. ${ }^{24 " W h o e v e r}$ kills a human being, not because that person (kills) another person or not because he causes damage to the earth, is as if he has killed the whole human being." (Surah Al-Maidah (5): 32).

The objectives of the national criminal law should be directed at: (1) safeguarding and protecting religions, so that religious adherents can carry out their religious teachings properly, and strengthen harmony between religious communities within the framework of the unitary state of Indonesia; (2) safeguarding and protecting the soul, so that murder and suicide do not occur, including maintaining honor which means not slandering other people and making false accusations against others; (3) safeguarding and protecting property, the meaning of which is prohibition against cheating, stealing, robbing, seizing,

\footnotetext{
22Tono, Sidik. (1993). "Elaborasi Nilai Hukum Pidana Islam dalam Perspektif Sosio-Kultural Bangsa Indonesia”, Paper in Jurnal al-Mawarid Indonesian Edition. Yogyakarta: UII Press, SeptemberDecember. h. 8-9.

${ }^{23}$ Anwar, Syamsul. (2000). Epistemologi Hukum Islam dalam al-Mustasyfa min Ilm al-Usul Karya alGazzali (450-505 / 1050-1111 AD), Dissertation, Yogyakarta: IAIN Sunan Kalijaga.

${ }^{24}$ QS. Al-Maidah (5): 32.
} 
corruption, bribery, including the category of safeguarding and protecting property is the determination of property rights, safeguarding and protecting Indonesia's homeland and spilled blood; (4) safeguarding and protecting offspring, demanding the prohibition of sexual deviance such as adultery, homosexual and lesbi.

Government policies with various kinds of legal sanctions against various crimes basically do not ignore the most basic element in law, namely putting the benefit or goodness of the law in a broad sense in realizing legal objectives. ${ }^{25}$ In the formation of the national criminal law in Indonesia, it is important to pay attention to preventive measures and formulate laws that are just for the benefit of society.

The provisions of punishment in Islamic criminal law can be used as a comparison with the objectives in national criminal law. The implementation of theories in the national criminal law system such as the existence of retributive theory, absolute theory, or a combination of the two is in line with the essence of punishing the perpetrator of a finger (criminal act) in Islamic criminal law. The things that are meant can be described as follows: ${ }^{26}$

First, to nurture society. In this case, the importance of punishment is as an effort to save society from the actions of the perpetrators of the finger. Second, as a preventive or special intervention for the perpetrator. If someone commits a criminal act, he will receive a reply in accordance with his actions. Third, as an educational and teaching effort (ta'dib and tadzib). This punishment is also an effort to educate the perpetrator to become a good person as well as a good member of society. The perpetrator is taught that the act he committed has disturbed the rights of others, whether moral, material or rape of the rights of others. In an effort to educate the perpetrator of this Jarimah, he will be able to know the obligations and rights of others.

Fourth, punishment for retribution for actions. It becomes a merit, every action is repaid with another equivalent action, good is rewarded with good deed, evil is also repaid with evil and that is something that is just. This is as Allah says: ${ }^{27}$ "Whoever does good as much as dzarrah, surely he will see (reply). And whoever does evil as big as dzarrah, surely he will see (reply) it too ". (Surah Al-Zalzalah (99): 7 and 8).

If the goal of imposing the sentence is not achieved, the last resort in positive law is to get rid of criminals through life imprisonment and / or capital punishment. Islamic law in the context of this crime has the same opinion, if by means of education it does not deter the perpetrator and actually endangers the community, then ta'zir punishment can be given in the form of death penalty or unlimited imprisonment.

According to the research results of the scholars, benefit can be classified into three aspects, namely: daruriyyah (primary), hajjiyyah (secondary), and tahsiniyyah (complementary). ${ }^{28}$ Meanwhile, one of the primary or fundamental aspects of human life which are intended to be protected and guaranteed for the benefit of the capital punishment is the human soul.

${ }^{25}$ Nuruddin, Amir. (1987). Ijtihad Umar ibn Khattab. Jakarta: Rajawali Press, p. 154.

${ }^{26}$ Hakim, Rahmat. (2000). Hukum Pidana Islam (Fiqh Jinayah). Bandung: Pustaka Setia. h. 64-66.

${ }^{27}$ QS. Al-Zalzalah (99): 7 and 8.

${ }^{28}$ Asy-Syatibi, al-Muwafaqat fi Usul al-Ahkam. Beirut: Dar al-Ma'rifah. II, 4. 
Detention is a rational reason for the imposition of a sentence. Its main objective is to prevent the recurrence of this criminal offense in the future. This explanation is projected in the future, namely in the interests of a preventive measure so that the violation does not occur again. Internally, the perpetrator will give up on repeating it again, and in general this side of deterrence is for the community not to commit their actions. This is different from the levy theory which tends to look back from the point in time of the criminal act. ${ }^{29}$

According to the author's perspective, it is impossible for the purpose of punishment to eradicate evil from the face of the earth. But at least, conviction causes the sense of justice of the victims to be realized. Criminalization, including capital punishment, is intended to realize legal objectives, namely: peace, justice, utility, and certainty (certainly). More specifically, Indonesia is experiencing a downturn in the law. So the existence of capital punishment is increasingly being felt, for extra-ordinary crimes, which result in many victims.

The philosophy of capital punishment for the Indonesian nation is inseparable from the views and attitudes of the Indonesian people as outlined in MPR Decree No. XVIII / 1998 which states that the views and attitudes of the Indonesian people regarding human rights are derived from religious teachings, the noble values of the nation's culture, and are based on Pancasila. Human rights are formulated substantially by using a normative, empirical, descriptive and analytical approach. That is, human rights are basic rights inherent in human beings that are natural and universal as gifts from God and function to ensure the survival, independence, development of humans and society which cannot be ignored, seized and violated by anyone. ${ }^{30}$ However, in relation to the public interest, human freedom must yield in relation to the dangers that exist and are real in life. In the view of Islam, the severity of this punishment is not due to disrespect for the human spirit, but because the crime has very painful consequences for the benefit of the victim and society in general.

Punishment in Islam is very much determined on the aims and objectives, as stated above, the punishment is carried out - including this death penalty (qisas) - as a form of confirmation of faith, a form of accountability from the perpetrator, improvement for the victim, and social improvement. Individual rights and the rights of the state have a relationship and differences which are important to emphasize in order to position the individual rights and where the rights of the state to protect its people. ${ }^{31}$

Determination of the type of capital punishment is still necessary, because in its formulation, punishment and punishment are intended as a function of controlling / controlling or influencing and justifying the criminal system. ${ }^{32}$ Therefore, until now, the application of the death penalty for convicts in

\footnotetext{
29 There have been quite a number of descriptions of the theories of punishment by Islamic criminal law reviewers.

${ }^{30}$ Lumbun, T. Gayus. "Hentikan Pidana Mati”. Kompas General Daily, February 28, 2003.

31Santoso, Topo. (2003). Pribumisasi Hukum Pidana Islam Penegakan Syari'at dalam Wacana dan Agenda Jakarta: Gema Insani Press, p. 104.

${ }^{32}$ Arief, Barda Nawawi "Ide-ide Dasar (Pokok-pokok Pemikiran) Perubahan/Pemabaharuan KUHP” Paper presented in the Public Discussion of the Criminal Code Bill and Press Freedom, Fac. Atma Jaya Yogyakarta Law, June 16, 2005.
} 
special and serious cases has still maintained its existence in the positive legal system in Indonesia.

The reform of the national criminal law emphasizes the importance of extracting legal principles. The position of legal principles in the national positive legal system is not legal or outside of positive law but has a constitutive function. Legal principles become one of the substantive elements of a legal system. The legal system has four elements, namely the existence of values that underlie the legal system (philosophie), legal principles, norms or laws / regulations (legal rules), and the legal community as supporters of the legal system (legal society). . These four basic concepts are arranged in a series of units that form a substantive system of law (national). ${ }^{33}$

The public always appears with an image that states that Islamic criminal law is up to date and not humanist. In fact, if a study is carried out in an academicsociological-philosophical manner, besides ideological-normative matters, it will basically be able to ward off this negative image. Isn't it true that all punishments contain violence, enforcement in themselves. Violence is actually needed as a preventive measure (special and general prevention) for the occurrence of criminal acts in people's lives. The cruelty and violence that occurs in societies where law enforcement is low is far greater and more destructive. This is where the relevance of respecting the rights of peace, tranquility and tranquility of others in the framework of respecting human rights. ${ }^{34}$

The difference between the conceptions of crime in Western law and shari'ah is actually not that much difference in the level of social order regulation. However, there are several principal differences between the theory and application of Western criminal law and Islamic criminal law. The clear differences that arise are in terms of the source of the law, the history of its formation, its relationship with morals, the purpose of punishment and other things. As a small illustration, namely that Islamic shari'ah through its legal institutions is to save moral values and create a harmonious life between communities, besides of course also to protect collective interests in the large building system of society. ${ }^{35}$

Islamic law besides experiencing contextualization with changing situations and conditions, Islamic law also has a liberating character. In a sense, Islam with its teachings; in this case it also touches the legal dimension, it is hoped that it can become a teaching that can answer various universal human problems regardless of religious, cultural and ethnic differences. Thus, Islamic rules are not rigid and rigid in facing the ever-changing social reality of society.

Adaptation of the law to changes in the social conditions of society is a necessity, because the law in this case follows the needs of society. ${ }^{36}$ Because

\footnotetext{
${ }^{33}$ Mudzakir. Internalisasi Nilai-nilai Islam dalam Proses Pendidikan Hukum. (Medan: Faculty of Law, Islamic University of North Sumatra (UISU), April 29, 2003), p. 5.

${ }^{34}$ For this description, see Muhammad, Rusjdi Ali. (2003). Revitalisasi Syariat Islam di Aceh, Problem, Solusi dan Implementasi. Jakarta: Logos, Discourse of Science. h.121-122 compare with Suma, Muhammad Amin "Menepis Citra Negatif Hukum Pidana Islam", in Arifin, Jaenal., dan Salim GP., M. Arskal (ed), Pidana Islam di Indonesia Peluang, Prospek dan Tantangan, Jakarta: Pustaka Firdaus. pp. 12-13.

${ }^{35}$ Santoso, Topo. op. cit. h. 20-22.

${ }^{36}$ Mas'ud, Muhammad Khalid. (1997). Islamic Legal Philosophy: A Study of Abu Ishaq al-Shatib's Life and Trought. Islamabad: Islamic Research Institute. h. 35.
} 
changes in a society can be about social values, social principles, patterns of behavior, organization, structure of social institutions, layers of society, and so on. ${ }^{37}$ Therefore, in today's social changes, developments that occur in law are reasonable and important variables in order to contribute to the construction of national law.

Theoretically, legal transplants such as those carried out by the current government are recognized as one of the best steps in solving the problem of legal pluralism, but in practice it does not automatically produce positive results. Because in reality an existing legal tradition is not passive and rigid, but always moves in accordance with the movement of the development of society itself, for example Islamic law, it cannot be said to be a stagnant legal system and never displays uniformity. As a result, when Islamic law was about to be adopted in the univication of national law, the first problem that arose was around the issue of Islamic law itself. 38

Based on the description of the purpose and concept of punishment as mentioned above, it can be said that it is in line with the concept in Islamic law in determining the punishment. The Islamic criminal system was built in order to protect the interests of the convicted person and society in general. The Islamic criminal system aims to enable people to save moral values and a harmonious life. 39

The process of legal unification in Indonesia must be able to create a sense of justice and the dignity of a judicial body, this requires seriousness to explore and discover laws that live in the midst of Indonesian society. In Indonesia, Pancasila is a way of life for the nation, and Pancasila is a crystallization of the values that are believed to be. i truth and owned by the Indonesian nation. The manifestation of these values according to Prof. Notonagoro can be concluded in three categories, namely: (1) values that underlie God's Law, (2) values that underlie nature, and (3) values that underlie moral law. ${ }^{40}$

In the perspective of the author, that the death penalty in Indonesia must still exist and even more effectively its implementation, as mandated by Allah SWT. Corruption crimes, narcotics and psychotropic crimes, human rights crimes, and terrorism crimes; Apart from planned and sadistic killings, treason against the existence of the state are types of crimes which are very detrimental to and disturb the stability of the normal life of the people and are properly punishable by death penalty. How to say that a person who kills is punished with the death penalty violates human rights, even though the murderer has violated other human rights by means of a criminal mechanism and a very large loss, even violating Allah's command on the prohibition of killing.

\footnotetext{
${ }^{37}$ Soekanto, Soejono. (1999). Pokok-pokok Sosiologi Hukum. Jakarta: Raja Grafindo Persada. h. 87-88. 38 Lukito, Retno. "Memahami Pro-Kontra Revisi KUHP”. Kompas General Daily. February 27, 2004.

${ }^{39}$ Audah, Abdul Qadir. (1982). Islamic System of Justice. Karachi: International Islamic Publisher. h. 74-75.

${ }^{40}$ Notonagoro. (1988). Pancasila Dasar Filsafat Negara. Jakarta: Bina Aksara. Cet. VII.
} 


\section{Closing}

Death penalty is one of the main crimes in the Criminal Code and is listed in other laws outside the Criminal Code since its inception until now it is still a matter of controversy. Those who are pro try to defend on the grounds that capital punishment is in accordance with the teachings of religion (Islam), the 1945 Constitution and Pancasila. Meanwhile, the contra argued that the death penalty was inhumane, contrary to the spirit of the constitution, and did not provide an opportunity for the convicted person to do good, or rehabilitate the perpetrator, or to correct the possibility of the judge being wrong in his decision. In the perspective of Islamic law, capital punishment reflects justice and balance with the actions perpetrated by the perpetrator against the victim, as is the application of qisas to a deliberate murder.

After discussing the juridical review of capital punishment in Indonesia from the perspective of Islamic law, there are several things that the author would suggest. First, the mechanism for the execution of capital punishment should be carried out in a more humane manner, that is, in addition to hastening the execution process, it is also carried out not with a gunman as it has been until now, but with a more polite mechanism such as using a syringe and accompanied by a companion. spiritual of each religion is convicted before the seconds of his execution. Second,It is better if after the clemency has been rejected, the execution should be carried out as soon as possible by stating the deadline for execution, or at the latest one year after the judge's decision has permanent legal force, or after the President's clemency has come down.

Wallahu al-a'lam bi al-shawab.

\section{Bibliography}

Adji, Oemar Seno et al (ed). 1986. . Kitab Undang-Undang Hukum Pidana ( KUHP). Jakarta: Ghalia Indonesia.

Anwar, Syamsul. (2000). Epistemologi Hukum Islam dalam al-Mustasyfa min Ilm alUsul Karya al-Gazzali (450-505 / 1050-1111 AD), Dissertation, Yogyakarta: IAIN Sunan Kalijaga.

Arief, Barda Nawawi "Ide-ide Dasar (Pokok-pokok Pemikiran) Perubahan/Pembaharuan KUHP" Paper presented in the Public Discussion of the Criminal Code Bill and Press Freedom, Fac. Atma Jaya Yogyakarta Law, June 16, 2005.

Arifin, Jaenal., \& Salim, M Arskal (ed). (2001). Pidana Islam Di Indonesia Peluang, Prospek, dan Tantangan. Jakarta: Pustaka Firdaus.

Asy-Syatibi, al-Muwafaqat fi Usul al-Ahkam. Beirut: Dar al-Ma'rifah. II.

Audah, Abdul Qadir. (1982). Islamic System of Justice. Karachi: International Islamic Publisher.

Azhary, M. Tahir. (1997). Negara Hukum Suatu Studi Tentang Prinsip-prinsip dilihat dari Hukum Islam Implementasinya pada Periode Madinah dan Masa Kini, 
Jakarta: Bulan Bintang. h. 38. Similar thing, Haikal, M. Husain. (1982). Sejarah Hidup Muhammad, Jakarta: Pustaka Jaya and Tintamas.

Basyir, Ahmad Azhar. (2001). Ikhtisar Fikih Jinayat (Hukum Pidana Islam). Yogyakarta: UII Press.

Coulson, Noel J. (1991). A History of Islamic Law, Edinburgh: University Press, I.

Hakim, Rahmat. (2000). Hukum Pidana Islam (Fiqh Jinayah). Bandung: Pustaka Setia.

Hasani, Ismail "Islam and Human Rights", source hukumonline, December 23, 2003.

Hitti, Philip K. (1973). The Story of Arabs, London: MacMillin

Hosen, Ibrahim. (1997). "Jenis-jenis Hukuman dalam Hukum Pidana Islam (Reinterpretasi terhadap Pelaksanaan aturan)", in Jamal D. Rahman, (1997). Wacana Baru Fiqih Sosial 70 tahun KH. Ali Yafie. Jakarta: Mizan.

Imam al-Ghazzali Said, et al (ed). (2005), Ahkam al-Fuqaha Solusi Problematika Aktual Hukum Islam Keputusan Muktamar, Munas dan Kombes Nahdlatul Ulama (1926-1999 AD), Surabaya: LTN NU East Java \& Diantama. h. 621622.

Lukito, Retno. "Memahami Pro-Kontra Revisi KUHP”. Kompas General Daily. February 27, 2004.

Lumbun, T. Gayus. "Hentikan Pidana Mati”. Kompas General Daily, February 28, 2003.

Mas'ud, Muhammad Khalid. (1997). Islamic Legal Philosophy: A Study of Abu Ishaq al-Shatib's Life and Trought. Islamabad: Islamic Research Institute.

Mudzakir. Internalisasi Nilai-nilai Islam dalam Proses Pendidikan Hukum. (Medan: Faculty of Law, Islamic University of North Sumatra (UISU), April 29, 2003).

Muhammad, Rusjdi Ali. (2003). Revitalisasi Syariat Islam di Aceh, Problem, Solusi dan Implementasi. Jakarta: Logos, Discourse of Science.

Nuruddin, Amir. (1987). Ijtihad Umar ibn Khattab. Jakarta: Rajawali Press.

Prododikoro, Wirdjono. (2003). Asas-asas hukum Pidana di Indonesia. Bandung: PT Refika Aditama.

Santoso, Topo. (2003). Pribumisasi Hukum Pidana Islam Penegakan Syari'at dalam Wacana dan Agenda Jakarta: Gema Insani Press.

Schacht, Joseph. (1964). An Introduction to Islamic Law, Oxford: Oxford University Press, I.

Soekanto, Soejono. (1999). Pokok-pokok Sosiologi Hukum. Jakarta: Raja Grafindo Persada.

Suma, Muhammad Amin "Menepis Citra Negatif Hukum Pidana Islam", in Arifin, Jaenal., dan Salim GP., M. Arskal (ed), Pidana Islam di Indonesia Peluang, Prospek dan Tantangan, Jakarta: Pustaka Firdaus. 
Tono, Sidik. (1993). "Elaborasi Nilai Hukum Pidana Islam dalam Perspektif SosioKultural Bangsa Indonesia”, Paper in Jurnal al-Mawarid Indonesian Edition. Yogyakarta: UII Press, September-December.

Yafie, Ali, "Konsep-konsep Hukum", in Budhy Munawar-Rahman (ed), 1995, Kontekstualisasi Doktrin Islam dalam Sejarah. Jakarta: Paramadina Foundation.

Notonagoro. (1988). Pancasila Dasar Filsafat Negara. Jakarta: Bina Aksara. Cet. VII. 